\title{
Talking about Islam and Democracy in Indonesia's Public Schools
}

\section{Legitimation and Qualification}

\author{
Sawyer Martin French \\ Research Fellow, Institute for International Studies, Universitas Gadjah Mada \\ Yogyakarta, Indonesia \\ Student, Sunan Kalijaga State Islamic University \\ Yogyakarta, Indonesia \\ sawyermfrench@gmail.com
}

\begin{abstract}
Is Islam compatible with democracy? The answer to this question hinges immediately on the degree to which Muslims themselves embrace the concept. This study evaluates how democratic ideas are both legitimated and qualified in Islamic education classes in Indonesian public high schools. These classes, mandatory for all Muslim students under the national curriculum, include a chapter that specifically addresses democracy as well as wider material touching on related values. This study draws on extensive fieldwork in public high schools in the province of Yogyakarta, original survey data from multiple provinces, and analysis of state-written Islamic education textbooks from the New Order to the present. In state-written textbooks, the portrayal of democracy is found to noticeably evolve as the state itself is transformed from a dictatorship into a democracy, demonstrating increasing support-with certain qualifications - for the idea of democracy as an Islamically legitimate mode of governance. Within classrooms, most Islamic education teachers also demonstrate acceptance of democracy on Islamic terms, although they should not be mistaken for liberal democrats. Overall, this article argues that Islamic education classes in Indonesian schools contribute not only to popular acceptance of democracy but also to the articulation of a distinctively illiberal vision for democracy among Muslim students in Indonesia.
\end{abstract}

Keywords - Indonesia, Islam, democracy, education

\section{INTRODUCTION}

Indonesia's national curriculum for Islamic education, mandatory for all Muslim students, includes a chapter focusing on democracy. This paper analyzes this discourse on democracy within Indonesian Islamic education, drawing on extensive fieldwork in Indonesian schools, analysis of government-produced Islamic education textbooks, and surveys of Islamic education teachers. Overall, I argue that these discussions about democracy in the national system of Islamic education play an important role in the legitimation of representative government from an Islamic perspective. In contemporary Indonesia, both Islamic education textbooks and teachers demonstrate a general acceptance of democracy. But while they largely embrace the mechanics of democracy, their political discourse also challenges certain liberal values traditionally considered essential to it. In Islamic education classrooms, democracy is lent legitimation with Islamic rhetoric, but it is also qualified and redefined on terms acceptable to the Indonesian Muslims shaping the discourse.

\section{DEMOCRACY IN ISLAMIC EDUCATION TEXTBOOKS}

In Islamic education classes in public high schools, the most common materials used are textbooks that are written, printed, and distributed by the government. ${ }^{1}$ Some schools choose to use textbooks from private publishers, but their content is still modelled on the chapter-by-chapter outline established by the national curriculum. Across the country, there are 1.6 million Muslim students enrolled per grade level at general public high schools, and each is assigned to use these government Islamic education textbooks or a privately published rendition of the same content. ${ }^{2}$ Here, I analyze the chapters from government Islamic education textbooks from 1994, 2006, and 2013 national curriculums that deal explicitly with democracy. The content is found to noticeably evolve as the state itself is transformed from a dictatorship into a democracy, demonstrating increasing support-with qualifications - for the idea of democracy as an Islamically legitimate mode of governance.

\section{A. During Suharto's Authoritarian New Order}

The 1994 curriculum's discussion of democracy reflects the interests of the authoritarian regime that produced it. Democracy comes up in the $11^{\text {th }}$ grade textbook in a chapter devoted to the Islamic concept of mushawarah, a derivative of the Arabic shura, meaning "consultation." Since the $19^{\text {th }}$ century, Islamic modernists have referenced shura to argue that Islam rejects tyranny and promotes representative government. After focusing mostly on the mechanics and ethics of mushawarah, the final paragraphs offer a diatribe apparently

\footnotetext{
${ }^{1}$ While the books are published by the Center for Curricula and Books in the Ministry of Education and Culture, they are typically written by a team of Islamic education teachers and employees recruited from the Ministry of Religion. Feisal Ghozaly, personal interview, 11 January 2017.

${ }^{2}$ Enrollment data obtained from the Ministry of Education and Culture's records for the 2015-2016 school year.
} 
directed at anyone who would use this concept to promote democracy.

The authors declare that mushawarah is practised in Indonesia's (largely powerless) regional and national parliaments in a system they call "Pancasila Democracy." The book then proceeds to describe Pancasila Democracy and its differences with traditional models of democracy:

Pancasila Democracy ... as far as possible pursues the path of mushawarah .... The process of governance in Indonesia does not have a pure separation of powers but follows a distribution of power on the model of a family. In Pancasila democracy that follows a family model, there is no opposition, no dictator and the oppressed majority, and no tyranny of the minority.

Unfortunately, we have no records of how this material was conveyed by teachers or received by students, though one might assume that this propaganda would not always have been taken at face value.

\section{B. In the Early Years of Indonesian Democracy}

In the first new legislation on education passed after the fall of Suharto, an aim of the national education system is declared to be "the development of potentials in students to ... become citizens that are democratic." This goal was reflected in the new Islamic education textbooks released as part of the 2004 curriculum (updated in 2006). On the surface, the textbooks seem to promote democracy as an Islamically legitimate mode of governance, but a closer look shows a more ambivalent attitude with the potential to confuse student readers.

A chapter in the $10^{\text {th }}$-grade textbook from 2006 is entitled "Democracy in the Verses of the Qur'an." It is an updated version of the mushawarah chapter from 1994, and the title is rather misleading, as it is very little in the chapter itself suggesting that democracy is supported by the Qur'an. Most of the chapter focuses on the mechanics of how to conduct mushawarah when deliberating on an important issue, mentioning only briefly that this "is often practised in democratic systems". The only other time democracy is mentioned, the authors emphasize the difference between it and democracy. Unlike mushawarah, they state, democracy "is not based on the rules found in the Qur'an and hadith. In a democracy, every decision that is collectively agreed upon must be obeyed, even if it conflicts with the Qur'an and hadith"

. This passage is highly ambivalent about the moral status of democracy. On the one hand, students are told that all democratic outcomes must be respected. On the other, the authors undermine the chapter title's suggestion that democracy has roots in the Qur'an by emphasizing crucial discrepancies between it and mushawarah. The government seemingly intends to lend Islamic legitimacy to the country's new political system, but students may be left more confused than convinced.

\section{In the 2013 National Curriculum}

The textbooks for the 2013 national curriculum overall offer a far more enthusiastic endorsement of democracy from an Islamic perspective, though it is not without qualification. The $12^{\text {th }}$-grade Islamic education textbook in the 2013 curriculum presents a significantly revised version of the mushawarah chapter from previous curricula, entitled "United in Diversity and Democracy." The chapter begins with the assertion that the most important part of democracy is the imperative for people to value and respect each other. These same values, the authors assert, are also part of Islam's mission for humanity, as expressed in "one of the hadith" (58). The authors then offer the following emphatic defence of democracy in Islam:

Democracy may be a term born in the West, but don't forget, Islam is accommodating towards anything that comes from the outside, West or East, as long as the values carried by it are following Islam's values, meaning it is Islamic.

Did you know? According to experts, the government led by the prophet Muhammad and the Rightly-Guided Caliphs was the most democratic form of government that has ever existed in the world, with the Medina Charter as its point of reference in organizing civil relations. In that era, all parts of society received equal recognition and respect.

This passage demonstrates a remarkable progression. After asserting that democracy cannot be rejected simply because the term originates in the West, they then recast the genealogy of democracy as actually emerging from Islam, lending it legitimacy as a system that is compliant with-even promoted by-Islam.

But the chapter concludes with a section entitled "Opinions of Ulama (Muslim Intellectuals) about Democracy," noting that there are two major camps: those who "reject it completely," and others who "accept it with certain qualifications". The authors proceed to offer short passages describing the political thought of five modern Islamic thinkers, one of whom rejects democracy as polytheism, and the rest of whom accept it with various qualifications forbidding any contradiction of Islamic doctrine. While this is not an emphatic, uncritical propagation of democracy, it is far more positive than the material presented under the 2006 curriculum. These books, produced by the political establishment, have gradually evolved to support the changing institutions of that establishment.

The many ambiguities found in the 2006 and 2013 textbooks' discussions of democracy should remind us of two things. First, while there is growing support for democracy within the world of Indonesian Islamic education, this does not signify an uncritical acceptance of it on western terms. Endorsements of representative government are still qualified by criticisms of secularism and any democratic outcomes that conflict with popular interpretations of Islam. Second, these ambiguities alert us to the critical agency of those who read and interpret these texts. When a single chapter includes content suggesting that democracy is both a system supported by Islam as well as a form of heretical polytheism, the conclusions students draw can depend significantly on their prior opinions and the direction of their teacher interlocutors. Islamic education teachers employed at each school play a crucial role in guiding students' understandings of the concepts involved. 


\section{ISLAMIC EDUCATION TEACHERS AND THEIR POLITICAL VIEWS}

The Indonesian state is deeply involved in the educational and professional lives of most Islamic education teachers in ndonesia. Most are trained at state institutions of higher education, ${ }^{3}$ where they complete government-designed coursework in both Islamic studies and modern pedagogy. Those teachers graduating from private institutions also receive coursework complying with government standards for institutional certification. Graduates are then certified and registered by government institutions, and most go on to be state-salaried civil servants. ${ }^{4}$ These teachers' opinions hold important implications for public opinion in Indonesia. Their discursive power stems from their institutionalized positions of authority, and it is compounded by a general culture of intellectual respect for authority in Indonesia.

With the government so highly involved in the training and employment of Islamic education teachers, we should not be surprised to find a majority adhering to a mainstream, establishment form of Islam, supported by and supportive of the contemporary political system. Despite occasional alarmism about extremism among Islamic education teachers, ${ }^{5}$ There is little evidence that most desire radical political change in Indonesia on Islamist terms. In my surveys of Islamic education teachers, only $12 \%$ of respondents in Java agreed with the statement, "It would be better if the Indonesian constitution and legal system were replaced with shari'a law." In interviews, many teachers expressed fears that students may be radicalized by Muslim activists from nearby university campuses or by online material, and they saw themselves as forming the front line for combatting these ideologies by equipping students with an adequate knowledge of moderate, establishment Islam.

In the manifestation of this support for a governmentfriendly, establishment Islam, Islamic education teachers surveyed for this study showed overwhelming acceptance of two of the main institutional pillars of the contemporary Indonesian state: Pancasila and democracy. $88 \%$ of respondents agreed with the statement, "Pancasila is and

\footnotetext{
${ }^{3}$ Among high school teachers surveyed in the province of

Yogyakarta, $65 \%$ of respondents indicated that they had received an undergraduate degree from a public Islamic higher educational institution (STAIN, IAIN, or UIN)

${ }^{4}$ The Ministry of Religion's records shows that out of a total of 186,906 Islamic education teachers employed at general, nonreligious schools during the 2014-2015 school year, 64\% were government-salaried civil servants. At the high school level, however, only approximately $40 \%$ of all 22,593 recorded guru PAI were civil servants during that same year since private school enrollment is far higher among general high school students (42\%) than it is at the primary level (12.4\%).

${ }^{5}$ See, for example: Varagur, "Majority of Religion School Teachers," Voice of America (27 December 2016), in which it is reported that $78 \%$ of Islamic education teachers support shari'a law, only later to mention that $82 \%$ of respondents in the same survey consider the existing political system to fulfill the shari 'ah. This survey was conducted in 2016 by PPIM in Jakarta.

${ }^{6}$ In Aceh (a province that enforces some shari 'ah legislation), however, a majority (74\%) agreed with that statement. This survey includes 141 valid responses from teachers in Yogyakarta and Jember in Java, as well as 23 responses from teachers in Aceh, collected May-August 2017.
}

ideology that complies [sesuai] with Islamic teachings," with only $6 \%$ disagreeing. A smaller majority $(72 \%)$ agreed with the statement, "Democracy is a political system that complies with Islamic teachings," with only $15 \%$ disagreeing. While democracy does not garner the same level of deference as Pancasila, it still enjoys widespread acceptance.

\begin{tabular}{|c|c|c|c|}
\hline \multicolumn{4}{|c|}{ "Democracy is a political system that complies with Islamic teachings." } \\
\hline $2 \% \quad \begin{array}{c}\text { Disagree } \\
13 \%\end{array}$ & $\begin{array}{c}\text { Unsure/Don't Know } \\
13 \%\end{array}$ & $\begin{array}{c}\text { Agree } \\
47 \%\end{array}$ & $\begin{array}{c}\text { Strongly Agree } \\
25 \%\end{array}$ \\
\hline Disagree, $15 \%$ & \multicolumn{3}{|c|}{ Agree, $72 \%$} \\
\hline
\end{tabular}

Figure 1: Valid responses: 156.

But acceptance of democracy does not necessitate political liberalism, and most Islamic education teachers hold political positions that could be categorized as decisively illiberal. Among teachers who agreed that democracy complies with Islamic teachings, 74\% disagreed with the statement "NonMuslims may become president of Indonesia," with only 14\% agreeing. By envisioning a political system where the highest positions of leadership are open only to Muslims, these teachers challenge the notion that democratization is somehow necessarily related to the secularization of politics.

This democratic illiberalism is not unique to Indonesia. In a 2013 Pew survey, 79\% of Muslims in Southeast Asia believe that "religious leaders should have political influence." Even in the West, $43 \%$ of Americans polled in a 2012 Gallup study would not vote for an atheist, and $40 \%$ would not vote for a Muslim. While liberalism and secularism may be traditionally associated with democracy in modern political thought, global political realities - and the desires of individual believing citizens - are challenging these assumptions.

\section{CONCLUSIONS: TOWARDS ILLIBERAL DEMOCRACY}

Both in Suharto's authoritarian New Order and in contemporary democratic Indonesia, the country's system of Islamic education has demonstrated support for the existing political system. Nowadays, Islamic education teachers and textbooks, operating from recognized positions of authority, help legitimate democracy as a political system that is acceptable to Islam. These textbooks, produced by the Ministry of Education and Culture, and these teachers, employed by the Ministry of Religion, are making a significant contribution to the democratization of Indonesian political culture.

But discourse in the world of Indonesian Islamic education is not one where western democratic ideas are uncritically adopted and propagated. Teachers and textbooks demonstrate critical engagement with the idea of democracy from within their political paradigm, challenging assumptions about the necessity of secularism and liberalism. In his research on postrevolutionary Egypt, Hamid observes the rise of political illiberalism to coincide with processes of democratization. Menchik describes a similar aversion to the idea of liberalism within Indonesia's democratic political discourse. I find that Indonesia's Islamic education teachers and textbooks reflect this larger trend towards illiberal democracy in Muslimmajority settings.

But the opinions of teachers and the contents of textbooks are not simply interesting because of how they reflect trends in 
society at large. Rather, these teachers and books should be seen collectively as influential actors in the shaping of public opinion in Indonesia. Because a majority of young Indonesians will read these books under the guidance of these teachers, the political discourse of the world of Islamic education may exercise significant influence on the future of democracy and Islamic political thought in Indonesia.

\section{ACKNOWLEDGMENT}

This paper draws on larger research conducted from 2016 to 2017 on Islamic education in public schools in Indonesia. I acknowledge the financial support of the National Science Foundation (NSF) in the initial fieldwork and the help of my colleagues at the Institute for International Studies (IIS) at UGM. I am also grateful to the many Islamic education teachers who have graciously been willing to participate in my research, whether by taking my survey, agreeing to an interview, or allowing me to observe their classes.

\section{References}

[1] “Data Referensi (Reference Data)." Kementrian Pendidikan dan Kebudayaan Republic Indonesia (Ministry of Religion and Culture of the Republic of Indonesia). http://referensi.data.kemdikbud.go.id.

[2] "Education Management Information System (EMIS)." Kementrian Agama Republik Indonesia (Ministry of Religion of the Republic of Indonesia). emispendis.kemenag.go.id.

[3] Jones, Jeffery M. "Atheists, Muslims See Most Bias as Presidential Candidates.” Gallup, 21 June 2012. www.gallup.com/poll/155285/atheists-muslims-biaspresidential-candidates.aspx. Accessed 4 September 2017.

[4] Ghozaly, Feisal. Personal interview, 11 January 2017.

[5] Hamid, Shadi. Temptations of Power: Islamists and Illiberal Democracy in a New Middle East. Oxford University Press, 2014.

[6] Menchik, Jeremy. Democracy and Islam in Indonesia: Tolerance without Liberalism. Cambridge University Press, 2016.

[7] Pendidikan Agama Islam untuk SMU / SMK: Kelas 3, Kurikulum 1994 (Islamic Education for General High Schools: $12^{\text {th }}$ Grade, 1994 Curriculum). Arranged by Direktorat Pembinaan Pendidikan Agama Islam pada Sekolah Umum Departmen Agama. Lubuk Agung, 1997 [1994].

[8] Pendidikan Agama Islam untuk SMA (Islamic Education for General High Schools). Written by Husni Thoyar. Kementrian Pendidikan Nasional, 2010 [2006].

[9] Pendidikan Agama Islam dan Budi Pekerti: Kelas XII (Islamic Education and Morals: $12^{\text {th }}$ Grade). Written by Feisal Ghozaly and HA. Sholeh Dimyathi. Kementrian Pendidikan dan Kebudayaan, 2015 [2013].

[10] Pew Research Center. The World's Muslims: Religion, Politics and Society. 30 April 2013.

[11] Shavit, Uriya. "Is Shura a Muslim form of Democracy? Roots and Systemization of a Polemic." Middle Eastern Studies vol. 46, no. 3, 2010, pp. 349-74.

[12] Undang-undang Republik Indonesia Nomor 20 Tahun 2003 tentang Sistem Pendidikan Nasional (Indonesian Law Number 20, Year 2003, regarding the National Education System).

[13] Varagur, Krithika. "Majority of Religion School Teachers in Indonesia Support Sharia Law." Voice of America, 27 December 2016, https://www.voanews.com/a/majority-of-religion-schoolteachers-in-indonesia-support-sharia-law/3652387.html.

$\begin{array}{lll}\text { Accessed } & 28 & \text { August }\end{array}$

2017. 